УДК $635.92(477.4 / 8)$

(C) 2016

Марченко А. Б., кандидат сільськогосподарських наук

Білоцерківський національний аграрний університет

\title{
ДЕКОРАТИВНІ КВІТКОВІ РОСЛИНИ В СТРУКТУРІ УРБОФЛОРИ ЛІСОСТЕПУ УКРАЇНИ
}

\section{Рецензент - доктор біологічних наук В. М. Черняк}

\begin{abstract}
За результатами моніторингу флористичного різноманіття декоративних квіткових рослин у структурі озеленення урбоекосистем Лісостепу України уточнено їх таксономічний склад, а саме представлені 118 видами із 58 родів 31 родини 16 порядків 2 класів. Домінуюче місие займає клас Dicotyledones, який представляє 66,1\%, налічує 14 порядків, серед яких за кількістю видів переважає Asterales - $34 \%$ видів. Клас Liliopsida представлений двома порядками, серед яких за кількістю видів переважає Asparagales Bromhead (70\%). 3а класифікацією I. Г. Серебрякова декоративні квіткові культури представлені наземними трав'яними (98,8\%), деревними життсвими формами (1,2\%), які в свою чергу представлені монокарпічними (71\%) та полікарпічними травами (27,8\%), кущами (1,2\%). За класифікацією Х. Раункієра, декоративні квіткові культури представлені такими життєвими формами: терофіти (71\%), криптофіти (27,8\%), фанерофіти (1,2\%). 3 а екологічними показниками всі наземні рослини відносно до вологи поділяються на мезофіти (52\%), ксеромезофіти (24\%), ксерофіти (21\%), мезогігрофіти (3\%); відносно до інтенсивності освітленості - геліофіти (81\%), сииооріти (19\%).
\end{abstract}

Ключові слова: урбофлора, вид, рід, родина, порядок, клас, терофіти, криптофіти, фанерофіти, мезофіти, ксеромезофіти, ксерофіти, мезогігрофіти, геліофіти, сциофіти.

Постановка проблеми. Рослинному покриву міст надається важлива роль у покращанні екологічного стану урбанізованого середовища, тому все більше уваги приділяється його цілеспрямованому розвитку. Оптимізація, раціональне використання, моделювання розвитку рослинного покриву міст неможливі без інвентаризації та аналізу урбанофлори. Найбільш важливим, але маловивченим компонентом урбоекосистеми Лісостепу України $є$ рослинний покрив декоративних квіткових рослин, який відіграє значну санітарну, оздоровчу, естетичну та освітню роль.

Аналіз останніх досліджень і публікацій, у яких започатковано розв'язання проблеми. Садово-паркові об'єкти та посадки рекреаційного і декоративного напряму (дендропарки, ботанічні сади, квіткові композиції в озелененні) $€$ невід'ємною частиною культурних ландшафтів
України. У композиційному рішенні садовопаркових об'єктів озеленення міст використовують аборигенні та інтродуковані види декоративних квіткових рослин. 3 початку XXI століття Україна переживає нову хвилю інтенсивного перетворення міських середовищ, використовуючи велике розмаїття нових рослин привезених iз різних географічних зон. Аналіз видового різноманіття цих культур із числа інтродукованих у різні роки в Україну свідчить, що для ландшафтно-інтегрованих колекцій придатні понад 400 видів та значне число їхніх культиварів. Великий потенціал у цьому відношенні мають і окремі родини, яким притаманна широка різноманітність за формою, розмірами і строками цвітіння рослин і їхніх геліо-, гідро- та трофоморф $[5,11$, $12,14]$, що займають вагоме місце у світовій культивованій флорі й, за результатами вивчення яких у останні роки створено наукову базу для їх інтродукції в Україну та вже акумульовано десятки видів і сортів у колекційних фондах $[2,19]$. Аналіз інтродукованих у ботанічні сади декоративних квітникових рослин свідчить про наявність великого за чисельністю і варіюванням різних ознак різноманіття зразків, колекційні фонди яких можуть створюватися у вигляді експозиційних ландшафтно-інтегрованих колекцій, функціонування яких покликане поліпшити видову насиченість, декоративні якості та пізнавальну цінність призначених для огляду ландшафтів [3, 7-9, 15].

Мета досліджень - провести моніторинг флористичного різноманіття декоративних квіткових рослин у структурі озеленення урбоекосистеми Лісостепу України.

Завдання - уточнити таксономічний склад декоративних квіткових рослин у структурі озеленення урбоекосистем.

Матеріали і методи досліджень. Флористичні дослідження проводили, застосовуючи прямі та опосередковані методи $[10,18,4]$. Відібрані гербарні зразки, які були камерально опрацьовані у лабораторії кафедри садово-паркового господарства Білоцерківського національного аграрного університету. Ідентифікацію фітобіотично- 
го складу здійснювали за $[13,6]$ та узгоджували iз сучасним номенклатурним списком судинних рослин України $[17,20]$. Класифікацію рослини за критерієм стану та способу захисту поновлення бруньок протягом несприятливого періоду проводили за системою життєвих форм Раункієра [1]. Основні категорії життєвих форм за ознаками тривалості життя всієї рослини та іiі «скелетних осей» декоративних квіткових рослин визначали за класифікацією I. Г. Серебрякова [16].

Результати досліджень. Протягом 2008-2015 рр. провели аналіз видового різноманіття агробіоценозів декоративних квіткових насаджень у структурі озеленення урбоекосистем Лісостепу України. Встановили, що декоративні квіткові культури відкритого грунту представлені двома класами, 16 порядками, 31 родиною, 58 родами, 118 видами. За кількістю видів домінуюче місце займає клас Dicotyledones (рис. 1), який представлений 78 видами $(66,1 \%)$ iз 46 родів (79,3\%) 26 родин $(83,8 \%) \quad 14$ порядків $(87,5 \%)$. Клас Liliopsida - 40 видами (33,9\%) із 12 родів $(20,7 \%) 5$ родин (16,2 \%) 2 порядків (12,5\%).

Клас Dicotyledones налічує 14 порядків, серед яких за кількістю видів домінуюче місце займає порядок Asterales, який представляє 34 \% видів від загальної кількості в цьому класі та 22 \% видів від загальної кількості декоративних квіткових культур відкритого грунту в структурі урбоекосистеми Лісостепу України. Інші порядки цього класу, а саме Saxifragales Dumort представлені 13 та 8,5 \%, Brassicales Bromhead - 8,9 та 5,9\%,
Ericales - 7,6 та 5,0\%, Lamiales Bromhead, Rosales, Ericales Dumort по 6,4 та 4,3 \% відповідно. Решта порядків представлені по 1-3 види (рис. 2). Порядок Asterales представлений 26 видами, які належать до 16 родів та однієї родини. У структурі цього порядку немає домінування серед родів, кожен рід представлений 1-3 видами (рис. 3).

Клас Liliopsida представлений двома порядками (рис. 4), серед яких за кількістю видів переважає Asparagales Bromhead, до якого належить $70 \%$ (28) видів цього класу 38 родів та 4 родин, порядок Liliales представлений 30 \% (12) видів 3 4 родів та однієї родини. У структурі порядку Asparagales домінуюче місце займає родина Iridaceae, яка представлена 46,4% видами від загальної кількості в цьому класі та $11 \%$ видами від загальної кількості декоративних квіткових культур відкритого грунту в структурі урбоекосистеми Лісостепу України, а родини Asparagaceae - 35,7 та 8,5\%, Amaryllidaceae J.St.Hil. - 10,7 та 2,5\%, Hemerocallidaceae - 7,2 та 1,7\% відповідно.

За кількістю видів у структурі класу Liliopsida домінуюче місце займають роди Iris, Gladiolus, Hosta Tratt., Lilium, Tulipa, які представляють кожен по 17,9 \% видів від загальної кількості в цьому класі та по 4,3 \% видів від кількості декоративних квіткових культур відкритого грунту в структурі урбоекосистеми Лісостепу. Решта родів представлені 2-3 видами (рис. 5).

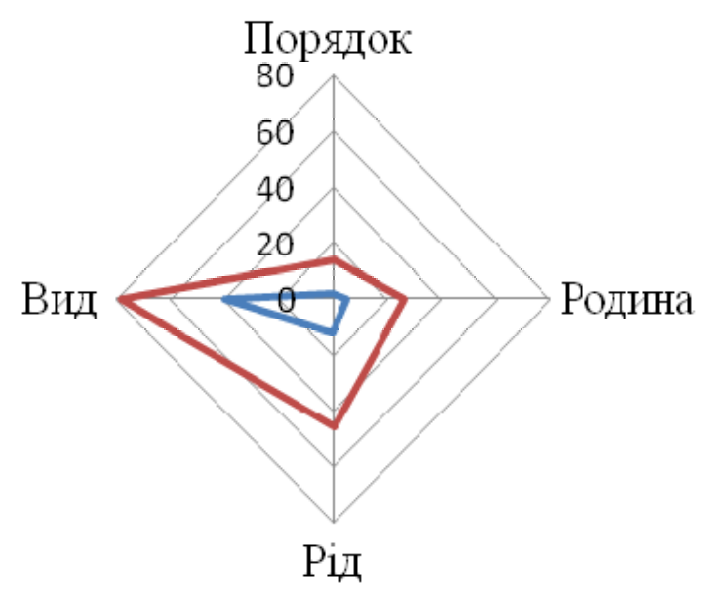

— Liliopsida —Dicotyledones

Рис. 1. Таксономічна структура представників декоративних квіткових культур відкритого грунту в урбоекосистемі Лісостепу Украӥни 


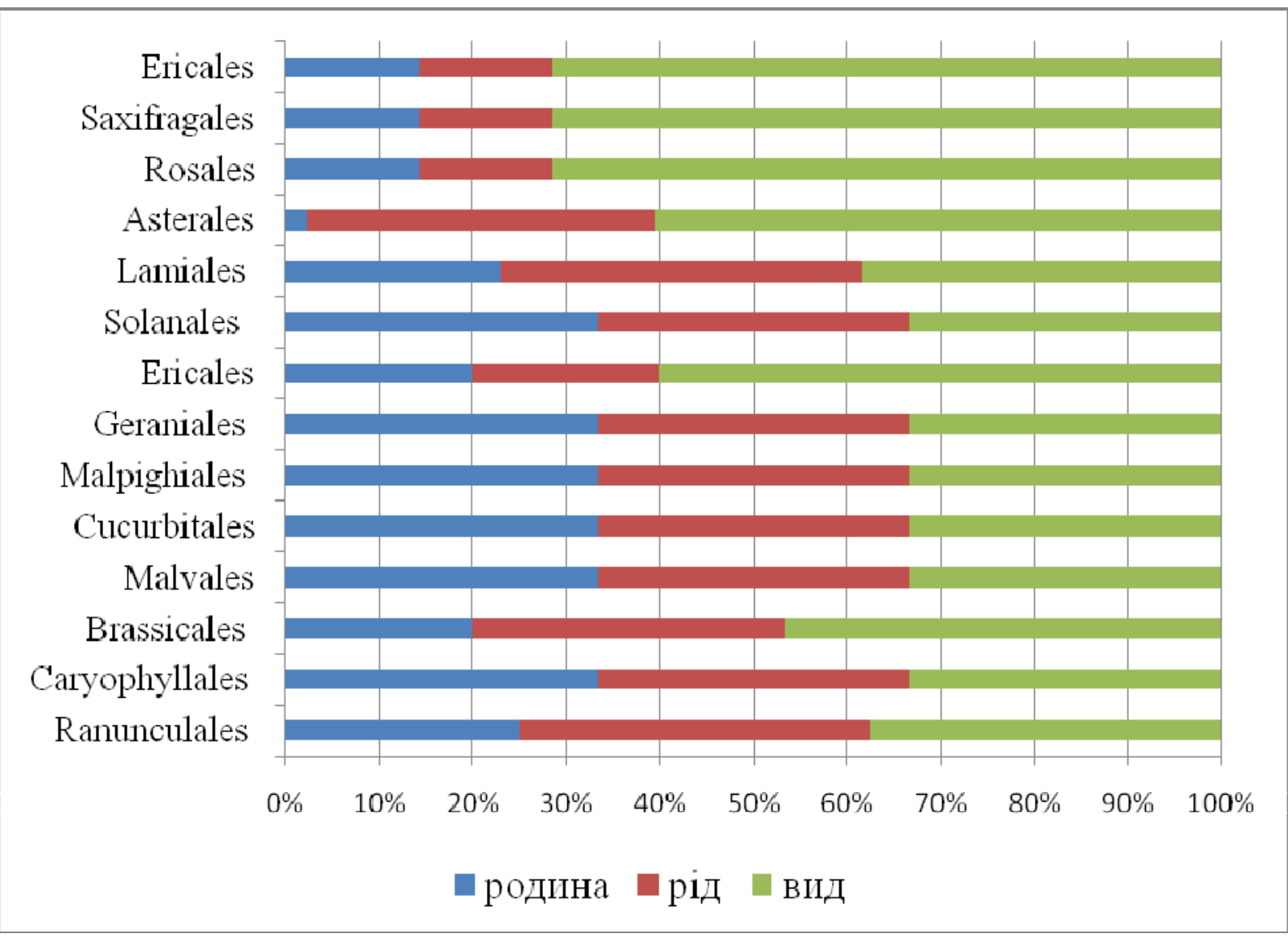

Рис. 2. Таксономічна структура представників декоративних квіткових культур відкритого трунту класу Dicotyledones

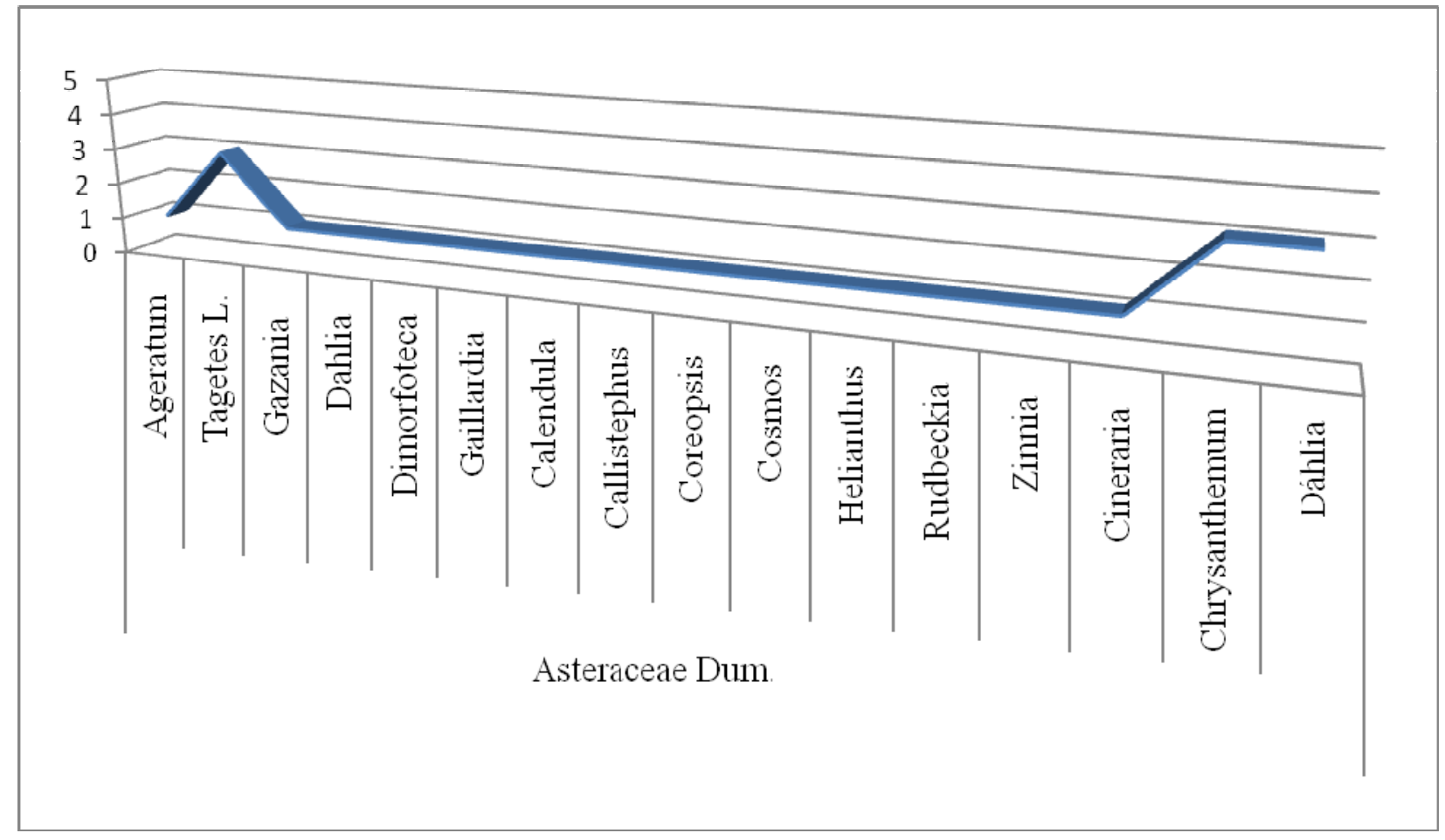

Рис. 3. Видовий склад представників декоративних квіткових культур відкритого трунту порядку Asterales 


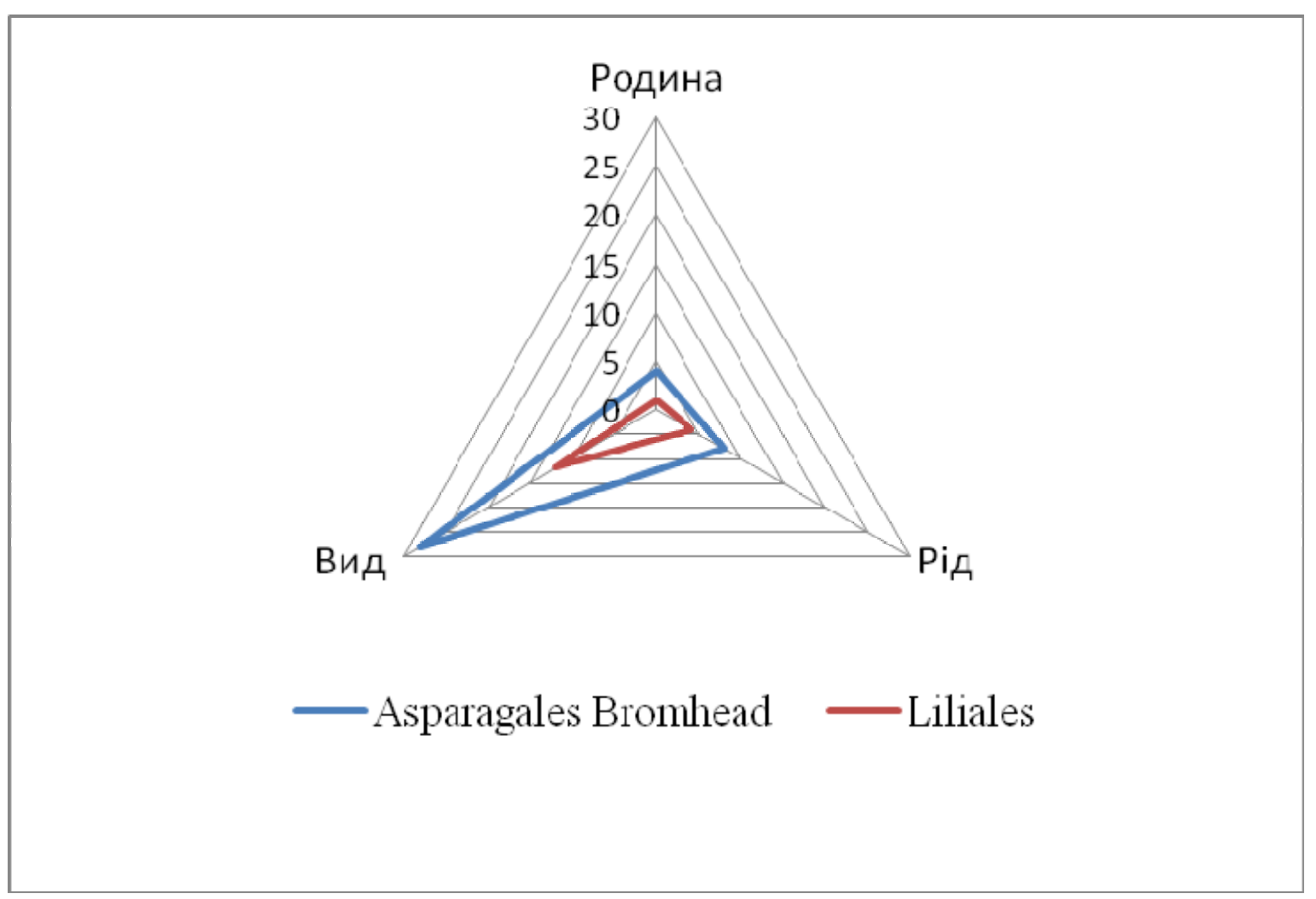

Рис. 4. Таксономічна структура представників декоративних квіткових культур відкритого трунту класу Liliopsida

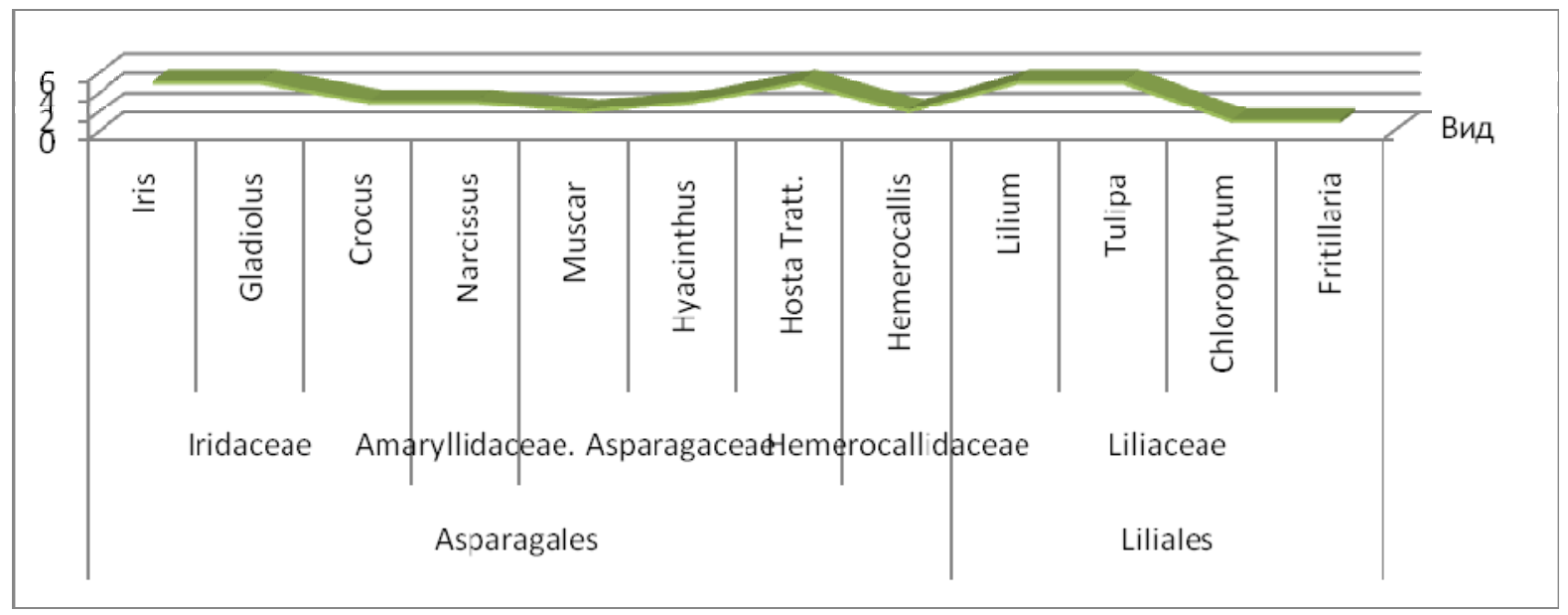

Рис. 5. Видовий склад представників декоративних квіткових культур відкритого трунту класу Liliopsida

За класифікацією І. Г. Серебрякова, декоративні квіткові культури відкритого грунту в структурі урбоекосистеми Лісостепу України представлені наземними трав'яними та деревними життєвими формами у співвідношенні 98,8 та $1,2 \%$ відповідно. Наземні трав'яні рослини, в свою чергу, представлені $71 \%$ монокарпічними та 27,8 \% полікарпічними травами, а деревні $1,2 \%$ кущами (рис. 6).

Клас Liliopsida представлений наземними трав'яними життєвими формами, серед яких $19 \%$ полікарпічних та $1,7 \%$ монокарпічних трав. Клас Dicotyledones представлений наземними трав'яними та деревними життєвими формами. Наземні трав'яні рослини у свою чергу представлені 69 \% монокарпічними та 8,6 \% полікарпічними формами, а деревні - 1,7 \% кущами від загальної кількості життєвих форм декоративних квіткових культур відкритого грунту в структурі урбоекосистеми Лісостепу. 


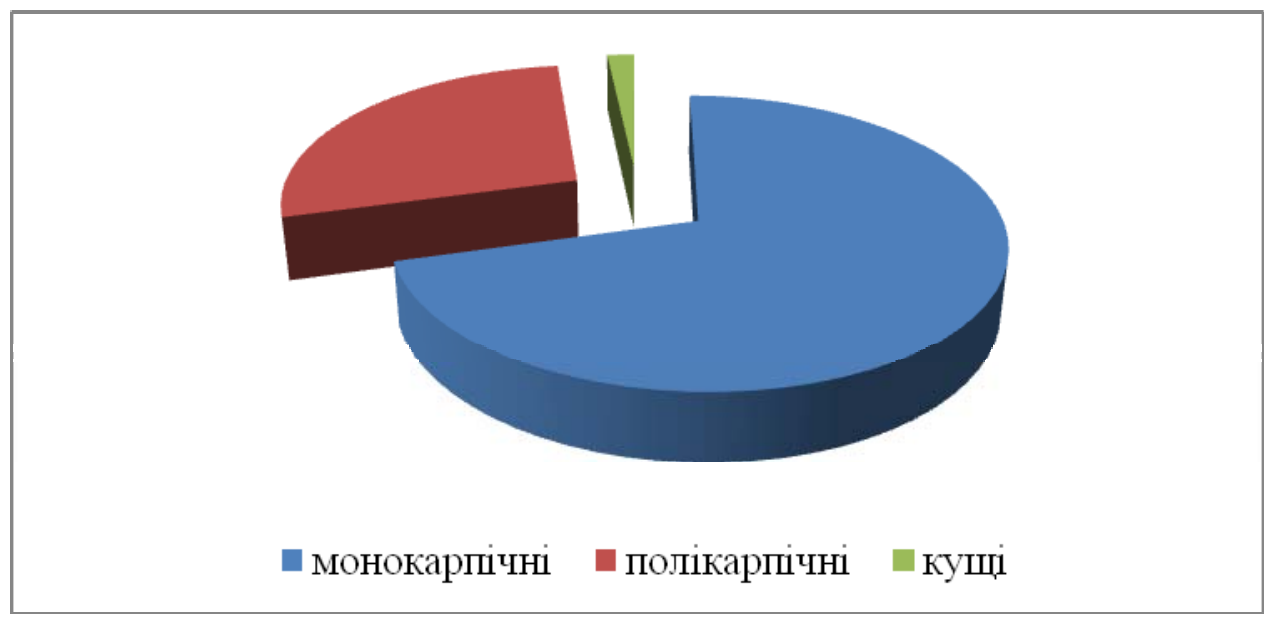

Рис. 6. Розподіл виявлених життевих форм декоративних квіткових культур відкритого трунту в структурі урбоекосистеми Лісостепу Украӥни за класифікацією I. Г. Серебрякова

За класифікацією Х. Раункієра, декоративні квіткові культури відкритого грунту в структурі урбоекосистеми Лісостепу України представлені 3-ма життєвими формами, а саме: $71 \%$ - терофіти, $27,8 \%$ - криптофіти та 1,2\% - фанерофіти. Клас Liliopsida представлений криптофітами, а клас Dicotyledones - терофітами (69\%), криптофітами $(8,6 \%)$ та фанерофітами $(1,7 \%)$.

Провівши аналіз декоративних квіткових культур відкритого грунту в структурі урбоекосистеми Лісостепу України за екологічними показниками встановили, що всі наземні рослини відносно вологи поділяються на: $52 \%$ - мезофіти, $24 \%-$ ксеромезофіти, $21 \%$ - ксерофіти, $3 \%$ - мезогігрофіти. Клас Dicotyledones представлений: 48,3 \% - мезофіти, 15,5\% - мезоксерофіти, $14 \%$ - ксерофіти та $2,4 \%$ - мезогідрофіти, а клас Liliopsida: 8,7\% - мезоксерофіти, $6 \%$ - ксерофіти, 3,4 \% - мезофіти та 1,7\% - мезогідрофіти від загальної кількості встановлених видів в урбоекосистемі. У структурі класів декоративні квіткові культури відкритого грунту класу Dicotyledones розподілені так: $61 \%$ - мезофіти, 19,6 \% - мезоксерофіти, 17,4 \% - ксерофіти, клас Liliopsida: $42 \%$ - мезоксерофіти, $34 \%$ - ксерофіти, $17 \%$ - мезофіти та $7 \%$ - мезогідрофіти від загальної кількості видів у класі. Отже, встановили, що домінуюче місце в озелененні урбанізованих екосистем Лісостепу України займають мезофітні рослини класу Dicotyledones.

Серед представників урбофлори декоративних квіткових культур мезофільними є монокарпічні трави, що становить 41,4 \% і представлені видами 3 родів Nigella L., Celosia L., Cleome L., Lobularia Desv., Tropaeolum L., Begonia (Tourn.) Linn., Ricinus L., Linum L., Primula, Ipomoeapurpurea, Petunia Juss., Antirrhinum L.,
Ageratum L., Tagetes L., Dahlia cav., Gaillardia Foyg., Calendula L., Callistephus Cass., Coreopsis L., Cosmos Cav, Helianthus L., Rudbeckia L., Zinnia L., Cineraria L. та полікарпічні (8,6 \%) Hyacinthus, Lilium, Chrysanthemum, Dáhlia, Paeonia L., кущі (1,7 \%) - Rosa. До екологічної групи мезоксерофіти в урбофлорі декоративних квіткових культур належать монокарпічні трави, що становить 22,4 \% і представлені видами з родів Papaver L., Eschscholzia Cham., Portulaca L., Iberis L., Lavatera L., Viola L., Pelargonium L'herit., Verbena L., Salvia L., Coleus Lour., Ocimum L., Ageratum L. та полікарпічні (12 \%) Crocus, Narcissus L., Muscar, Tulipa, Fritillaria, Sedum L., Phlox L. У структурі урбоекосистеми Лісостепу України ксерофітні декоративні квіткові культури представлені монокарпічними травами, що становить $12 \%$, - види 3 родів Chlorophytum KerGawl., Kochia Roth, Matthiola R. Br., Iberis L., Ocimum L., Gazania Gaertn., Dimorfoteca Moench, та полікарпічними (5,1%) Iris, Gladiolus, Hosta Tratt. Мезогігрофітні декоративні квіткові культури представлені полікарпічними травами видів 3 роду Hemerocallis L. та монокарпічними - Impatiens L., що становить по 1,7 \% від загальної кількості.

Відносно інтенсивності освітленості $81 \%$ декоративних квіткових культур урбоекосистеми Лісостепу України є геліофіти та $19 \%$ - сциофіти. До геліофітів належать види 3 родів Iris, Gladiolus, Crocus, Narcissus L., Muscar, Hyacinthus, Tulipa, Chlorophytum, Fritillaria, Nigella L., Eschscholzia Cham., Portulaca L., Celosia L., Ricinus L., Cleome L., Lobularia Desv., Matthiola R. Br., Iberis L., Tropaeolum L., Lavatera L., Linum L., Pelargonium L'herit., Ipomoeapurpurea, Petunia Juss., Antirrhinum L., 
Verbena L., Salvia L., Coleus Lour, Ocimum L., Ageratum L., Tagetes L., Dahlia Cav., Dimorfoteca Moench, Gaillardia Foyg., Calendula L., Coreopsis L., Cosmos Cav., Helianthus L., Rudbeckia L., Zinnia L., Cineraria L., Chrysanthemum, Dáhlia, Rosa, Paeonia L., Sedum L., Phlox L., а до сциофiтів належать види 3 родів Hosta Tratt., Hemerocallis L., Lilium, Papaver L., Kochia Roth, Begonia (Tourn.) Linn., Viola L., Impatiens L., Primula, Gazania Gaertn., Callistephus Cass.

Представники порядків Asterales L., Brassicales, Caryophyllales Perleb., Cucurbitales Dumort., Ericales Dumort., Ranunculales Dumort, Malvales Dumort., Malpighiales Mart., Geraniales Dumort, Solanales Dumort, Lamiales Bromhead, Rosales L., Saxifragales Dumort в урбоекосистемі Лісостепу України використовуються як декоративні культивовані рослини і мають антропогенне місцезростання. Види використовуються за планувальної організації об'єктів рекреаційного простору та ландшафтних фрагментів територій різного функціонального призначення (виробничих, житлових, громадських, міських і заміських). Домінування за композиційного рішення квіткового оформлення рекреаційних територій, спеціалізованих та поліфункціональних парків мають види 3 родів Ageratum L., Tagetes L., Callistephus Cass., Rudbeckia L., Matthiola R. Br., Iberis L., Tropaeolaceae DC., Portulaca L., Amaranthacae Juss, Begonia (Tourn.) Linn., Impatiens L., Primula L., Antirrhinum L., Verbena L., Salvia L., Linum L., Viola L.

Усі види класу Liliopsida, представники класу Dicotyledones, а саме: родів Gazania Gaertn., Dahliacav., Dimorfoteca Moench, Gaillardia Foyg, Calendula L., Callistephus Cass., Coreopsis L., Cosmos Cav., Helianthus L., Rudbeckia L., Zinnia L., Cineraria L., Lobularia Desv., Matthiola R. Br., Iberis L. та види Lobulariamaritima (L.) Desv., Matthiolaincana (L.) R. Br., Matthiolabicornis (Sibth.Et Smith) DC., Iberisamara L., Iberisumbellate L., Cleome L., Cleomespinosa Jacq, Tropaeolum L., Tropaeolummajus L., Portulaca L., Celosia L., Celosiaargentea L., Kochia Roth., Kochiascoparia L. Schrad., Begonia (Tourn.) Linn., Impatiens L., Primula L., Antirrhinum L., Verbena L., Salvia L., Coleus Lour., Ocimum L., Ricinus L., Linum L., Viola L., Lavatera L., Malva L. використовуються переважно під час облаштування малих рекреаційних територій та в садах житлових районів.

За маршрутного обстеження рекреаційних територій $з$ використанням квіткових насаджень урбоекосистем Лісостепу України встановили, що види Portulacagrandiflora Hook., Celosiaar- gentea L., Kochiascoparia L. Schrad., Callistephuschinensis L., Iberis L., Malvasylvestris L., Lavateratrimestris L. мають властивість синантропії.

В урбоекосистемі декоративні квіткові рослини відкритого грунту порядку Asterales Lindl. (1833) представлені родиною Asteraceae Dum., родами Ageratum L., Tagetes L., Gazania Gaertn., Dahlia cav., Dimorfoteca Moench, Gaillardia Foyg, Calendula L., Callistephus Cass., Coreopsis L., Cosmos Cav., Helianthus L., Rudbeckia L., Zinnia L., Cineraria L. та видами Ageratumhoustonianum Mill., Tagetespatula L., Tageteserecta L., Tagetestenuifolia Cav., Gazaniarigens (L.) Gaertn., Dahliapinnata Cav., Dimorfotecasinuate DC., Gaillardiapulchella Foug., Calendulaofficinalis L., Callistephuschinensis L., Coreopsistinctoria Nutt., Cosmosbipinnatus Cav., Helianthus annuus L., Rudbeckia bicolor Nytt., Zinniaelegans Jacq., Cineraria hybrid hort. Порядок Brassicales Bromhead представлений родинами Cleomaceae Bercht. \& J. Presl, Brassicaceae Burnett, Tropaeolaceae DC., 5 родами та 8 видами, домінуюче місце за кількістю видів займає родина Brassicaceae Burnett (75\%), яка представлена родами Lobularia Desv., Matthiola R. Br., Iberis L. та видами Lobulariamaritima (L.) Desv., Matthiolaincana (L.) R. Br., Matthiolabicornis (Sibth.Et Smith) DC., Iberisamara L., Iberisumbellate L., інші родини представлені по одному роду та одному виду: родина Cleomaceae Bercht. \& J. Presl - Cleome L., Cleomespinosa Jacq, родина Tropaeolaceae DC. - Tropaeolum L., Tropaeolummajus L. відповідно.

Декоративні квіткові рослини відкритого грунту порядку Caryophyllales Perleb представлені трьома родинами, кожна родина представлена одним родом та одним видом: родина Portulaceae Juss. - родом Portulaca L., видом Portulacagrandiflora Hook., родина Amaranthacae Juss - Celosia L. та Celosiaargentea L., родина Chenopodiaceae Vent. - Kochia Roth. та Kochiascoparia L. Schrad. Порядок Cucurbitales Dumort. (1829) представлений родиною Begoniaceae C. A. Agardh., родом Begonia (Tourn.) Linn., видом Begoniasemperflorens L.; порядок Ericales - родинами Balsaminaceae A. Richard, Primulaceae, родами Impatiens L., Primula L. та видами Impatiensbalsamina L., Primulaauricula L.; порядок Lamiales Bromhead - 3 родинами Scrophulariaceae Juss., Verbenaceae Jaume, Lamiaceae Lindley, 5 родами Antirrhinum L., Verbena L., Salvia L., Coleus Lour., Ocimum L. та 5 видами Antirrhinummajus L., Verbenahybrida hort, Salviasplendens Sello ex Nees, Coleusblumei Benth., Ocimum basilicum L.; порядок 


\section{СІЛЬСЬКЕ ГОСПОДАРСТВО. РОСЛИННИЦТВО}

Malpighiales Mart. - родинами Euphorbiaceae Juss., Linaceae S.F. Gray., Violaceae Batsch, родами Ricinus L., Linum L., Viola L. та видами Ricinuscommunis L., Linumgrandiflorum Dest., Violawittrockiana Gams.; порядок Malvales Dumort. - родиною Malvaceae Juss., родами Lavatera L. та Malva L., видами Malvasylvestris L., Lavateratrimestris L.

Урбофлора Лісостепу України порядку Asterales L. представлена наземними трав'яними монокарпічними життєвими формами, за вимогами до екологічних факторів види відносно вологи належать до двох екологічних груп - мезофіти 86 \% (Ageratum L., Tagetes L., Gazania Gaertn., Gaillardia Foyg, Calendula L., Callistephus Cass., Coreopsis L., Cosmos Cav., Helianthus L., Rudbeckia L., Zinnia L., Cineraria L.), ксерофіти - 14 \% (Dahliacav., Dimorfoteca Moench.), відносно інтенсивності освітлення всі види - геліофіти. Урбофлора порядку Brassicales представлена наземними трав'яними монокарпічними життєвими формами, за вимогами до екологічних факторів види відносно вологи належать до двох екологічних груп - мезофіти (Cleomespinosa Jacq., Lobulariamaritima (L.) Desv., Tropaeolummajus L.), ксерофіти (Matthiolaincana (L.) R.Br., Matthiolabicornis (Sibth. Et Smith) DC., Iberisamara L., Iberisumbellate L.), відносно інтенсивності освітлення всі види - геліофіти. Урбофлора порядку Caryophyllales Perleb представлена наземними трав'яними монокарпічними життєвими формами, за вимогами до екологічних факторів види відносно вологи належать до двох екологічних груп - мезофіти (Celosiaargentea L.), ксерофіти (Portulacagrandiflora Hook., Kochiascoparia L. Schrad.), щодо інтенсивності освітлення - геліофіти (Portulacagrandiflora Hook., Celosiaargentea L.) та сциофіти (Kochiascoparia L. Schrad.). Порядок Cucurbitales Dumort. (1829) представлений наземними трав'яними монокарпічними життевими формами, за вимогами до екологічних факторів відносно вологи є мезофітом, щодо інтенсивності освітлення - сциофіт. Порядок Ericales представлений наземними трав'яними монокарпічними життєвими формами, за вимогами до екологічних факторів види відносно вологи належать до двох екологічних груп: мезофіти (Primulaauricula L.), мезогігрофіти (Impatiensbalsamina L.), щодо інтенсивності освітлення - всі види сциофіти. Порядок Lamiales Bromhead

\section{БІБЛІОГРАФІЯ}

1. Андреева И. И., Родман Л. С. Ботаника / И. И. Андреева, Л. С. Родман. - [2-е изд., пере- представлений наземними трав'яними монокарпічними життєвими формами, за вимогами до екологічних факторів види відносно вологи належать до трьох екологічних груп: мезофіти (Antirrhinummajus L.), ксерофіти (Ocimum basilicum L.), ксеромезофіти (Verbenahybrida hort, Salviasplendens Sello ex Nees, Coleusblumei Benth.), щодо інтенсивності освітлення всі види геліофіти. Порядок Malpighiales Mart. представлений наземними трав'яними монокарпічними життєвими формами, за вимогами до екологічних факторів види порядку Malpighiales відносно вологи належать до двох екологічних груп: мезофіти (Ricinuscommunis L., Linumgrandiflorum Dest.), ксеромезофіти (Violawittrockiana Gams.), щодо інтенсивності освітлення - геліофіти (Ricinuscommunis L., Linumgrandiflorum Dest.) та сциофіти (Violawittrockiana Gams.). Порядок Malvales Dumort представлений наземними трав'яними монокарпічними життєвими формами, за вимогами до екологічних факторів види відносно вологи належать до екологічних груп ксеромезофіти, щодо інтенсивності освітлення геліофіти.

Висновок. У результаті моніторингу насаджень декоративних квіткових культур відкритого грунту за озеленення урбоекосистеми Лісостепу з'ясували таксономічний склад. Урбофлора представлена 118 видами із 58 родів 31 родини 16 порядків 2 класів. За кількістю видів домінуюче місце займає клас Dicotyledones, який представлений 78 (66,1 \%) видами, а клас Liliopsida 40 (33,9 \%) видами. За класифікацією І. Г. Серебрякова, декоративні квіткові культури відкритого грунту в структурі урбоекосистеми Лісостепу України представлені наземними трав'яними та деревними життєвими формами у співвідношенні 98,8 та 1,2 \% відповідно. Наземні трав'яні рослини, в свою чергу, представлені на $71 \%$ монокарпічними та 27,8 \% - полікарпічними травами, а деревні - 1,2 \% кущами. За класифікацією X. Раункієра, декоративні квіткові культури представлені 3 життєвими формами, а саме: $71 \%$ - терофіти, 27,8 \% - криптофіти та $1,2 \%$ - фанерофіти. За екологічними показниками декоративні квіткові культури відносно вологи представлені: $52 \%$ - мезофіти, $24 \%$ - ксеромезофіти, $21 \%$ - ксерофіти, $3 \%$ - мезогігрофіти; щодо інтенсивності освітленості: $81 \%$ - геліофіти, $19 \%$ - сциофіти.

раб. и доп.]. - М. : Колос, 2002. - 488 с.

2. Буйдін Ю. В. Використання тіневитривалих 
багаторічних трав'янистих рослин для створення тематичних композицій у ботанічних садах та дендропарках / Ю.В.Буйдін, О.П.Перебойчук, Н. А. Андрух // Ландшафтная архитектура в ботанических садах и дендропарках : материалы Междунар. конф. (Киев, 8-11 июня 2011 г.). К. : [б.в.], 2011. - С. 153-158.

3. Вивчення світового біорізноманіття квітниково-декоративних рослин, їх інтродукція та селекція : звіт про НДР (заключний) / Національний ботанічний сад ім. М. М. Гришка НАН України. - № 0204U003556; Інв. № 0199 U003057. - K., 2003. - 129 c.

4. Геоботаніка : тлумачний словник / [Якубенко Б. Є., Попович С. Ю., Григорюк І. П., Мельничук М. Д.]. - К. : Фітосоціоцентр, 2010. - 420 с.

5. Горай Г. О. Декоративні види родини макових (Papaveraceae Juss.) в умовах Лісостепу України: інтродукційна оцінка, морфобіологічні особливості, перспективи практичного використання : дис. ... к.б.н. : спец. 03.00.05 «Ботаніка»/ Г. О. Горай. - К., 2011. - 175 с.

6. Декоративные растения открытого и закрытого грунта / [Приходько С. Н., Яременко Л. М., Черевченко Т. М. и др.] ; под общ. ред. А. М. Гродзинского. - К. : Наук. думка, 1985. - 664 с.

7. Каталог растений Криворожского ботанического сада / [Бойко Л. И., Василенко Е. В., Вечканова Л. В. и др.]. - К. : Фитосоциоцентр, 2002. $164 \mathrm{c}$.

8. Каталог растений Центрального ботанического сада им. Н. Н. Гришко / [Афанасьева Е. В., Булах П. Е., Галицкая А. Ф. и др.]. - К. : Наук. думка, 1997. -435 с.

9. Каталог цветочно-декоративных травянистых растений ботанических садов СНГ и стран Балтии. - Минск : изд-во Э. С. Гальперин, 1997. $476 \mathrm{c}$.

10. Методы изучения лесных сообществ / [Андреева Е. Н., Баккал И. Ю., Горшков И. И. и др.]. СПб. : НИИ Химии СПбГУ, 2002. - 240 с.

11. Музичук Г. М., Рахметов Д. Б. Види квітникових рослин родини мальвових (Malvaceae
Juss.) у декоративному садівництві світу, перспективи їх використання в Україні / Г. М. Музичук, Д. Б. Рахметов // Роль ботанічних садів у зеленому будівництві міст, курортних та рекреаційних зон. - Одеса : ЛПЛАТСТАР, 2002. Ч. II. - C. 51-53.

12. Музичук Г. М., Перебойчук О. П. Квітниково-декоративні рослини роду Anemone L. у культигенній флорі світу та перспективи їх інтродукції в Україну / Г. М. Музичук, О. П. Перебойчук // Інтродукція рослин. - 2009. - №4. - С. 29-40.

13. Определитель высших растений Украины / [Доброчаева Д. Н., Котов М. И., Прокудин Ю. Н. и др.]. - К. : Наук. думка, 1987. - 548 с.

14. Прокопчук В. М. Інтродукція в Лісостеп України видів квітниково-декоративних рослин Scrophulariaceae Juss. : дис. ... к.б.н. : спец. 03.00.05 «Ботаніка» / В. М. Прокопчук. - К., 2005. $178 \mathrm{c}$.

15. Розширення генофонду квітниководекоративних рослин шляхом інтродукції та селекції : звіт про НДР (заключний) / Національний ботанічний сад ім. М. М. Гришка НАН України. - № $0194 \mathrm{U} 009083$; інв. № 0299U004067. - K., 1998. - $130 \mathrm{c}$.

16. Серебряков И. Г. Основные направления эволюции жизненных форм у покрытосеменных растений / И. Г. Серебряков // «Бюлл. МОИП», отд. биол. - Т. 60. - Вип. 3, 1955. - С. 71.

17. Собко В. Г. Визначник рослин Київської області / В. Г. Собко. - К. : Фітосоціоцентр, 2009. - $374 \mathrm{c}$.

18. Шмидт В. М. Статистические методы в сравнительной флористике / В. М. Шмидт. - Л. : изд-во Ленингр. ун-та, 1980. - 176 с.

19. Erchard W. Hemerocallis / W. Erchard. London : B.T. Batsford Limited, 1992. - 160 p.

20. Mosyakin S. L., Fedoronchuk M. M. Vaskular Plants of Ukraine : A Nomenclatural Checklist / S. L. Mosyakin, M. M. Fedoronchuk. - Kiev : National Academy of Sciences of Ukraine M. G. Kholodny Institute of Botany, 1999. - XXIII. - $346 \mathrm{p}$. 